\title{
Haematological and haemorheological changes associated with cigarette smoking
}

\author{
G GALEA, RJL DAVIDSON \\ From the Haematology Unit, Department of Pathology, Aberdeen Royal Infirmary, Aberdeen
}

SUMMARY A prospective study was undertaken to establish the haematological-and haemorheological changes associated with long standing cigarette smoking in 20 heavy smokers and to assess whether any such changes were reversible after smoking was stopped. Highly significant differences were observed in whole blood viscosity, plasma viscosity, plasma fibrinogen concentrations, packed cell volume, and carboxyhaemoglobin concentrations between smokers and non-smokers. Ten of the subjects were followed up for two weeks after stopping smoking by which time whole blood viscosity and carboxyhaemoglobin concentrations had improved significantly and indications of improvement could be seen in all other measurements. Two of these subjects were further followed up for two months when all the measured variables were comparable with those in non-smokers. No correlation could be established between carboxyhaemoglobin concentration and any of the other variables. Although patients' compliance may be difficult to obtain, further prospective studies would be required to confirm our findings.

As a cause of disease and death smoking is today what the great epidemics were to previous generations. It is estimated that in Britain alone as many as 100000 deaths occur each year as a result of smoking, including 25000 in people under the age of 65 . In spite of this there are still almost 20 million smokers in Britain. ${ }^{1}$

Since the early 1950 s several studies have shown the relation between smoking and peripheral vascular disease. The reasons, however, for this association are not always clear. Various suggestions link endothelial damage by constituents of tobacco smoke, accumulation of fibrin, and binding of low density lipoprotein with the development of atherosclerotic lesions. ${ }^{23}$ Moreover, in recent years it has been increasingly recognised that alterations in the blood itself, particularly in its flow properties, have an important pathological role. ${ }^{4} \mathrm{~s}$ Thus the main aims of our study were to establish the haemorheological changes associated with chronic cigarette smoking; to assess whether any such changes were reversible after smoking stopped; and finally, to study the relation between carboxyhaemoglobin and the variables measured. This was undertaken because carboxyhaemoglobin concen-

Accepted for publication 13 May 1985 trations have frequently been taken as an index of inhalation of smoke. ${ }^{6}$

\section{Patients and methods}

Twenty smoking volunteers, comprising 12 men and eight women with a mean age of 39 years (range 27-67), were investigated together with 20 nonsmoking controls matched for sex and age. All test subjects were heavy chronic smokers (15-60 cigarettes a day for $15-45$ years). Ten were reinvestigated two weeks after completely or near completely stopping smoking (eight had stopped completely, and one continued to smoke two cigarettes a day and one five cigarettes a day). Two of these were further investigated two months after giving up smoking.

\section{INVESTIGATIONS}

1 Coulter S Plus profile and microscopy of Romanowsky stained peripheral blood film.

2 Whole blood viscosity measured at $37^{\circ} \mathrm{C}$ at shear rates of $0 \cdot 1,1,10$ and 100/s (Contraves LS 30).

3 Plasma viscosity measured at $25^{\circ} \mathrm{C}$ (CoulterHarkness capillary viscometer).

4 Red cell filtration measured by the Reid and Dormandy filtration technique, ${ }^{7}$ using $5 \mu$ Nucleopore polycarbonate membranes specifically 
Table 1 Significant haematological and haemorheological changes associated with cigarette smoking

\begin{tabular}{|c|c|c|c|c|c|}
\hline & \multicolumn{2}{|c|}{ Smokers } & \multicolumn{3}{|c|}{ Non-smokers } \\
\hline & Mean & $S D$ & Mean & $S D$ & $p$ \\
\hline $\begin{array}{l}\text { Whole blood viscosity (mP } \\
0 \cdot 1 / \mathrm{s} \\
1 \cdot 0 / \mathrm{s} \\
10.0 / \mathrm{s} \\
100 / \mathrm{s} \\
\text { Plasma viscosity (mPa.s) } \\
\text { Haemoglobin b (g/dl) } \\
\text { Packed cell volume } \\
\text { Carboxyhaemoglobin }(\%)\end{array}$ & $\begin{array}{l}45 \cdot 5 \\
18 \cdot 8 \\
8 \cdot 3 \\
4 \cdot 9 \\
1.67 \\
14 \cdot 6 \\
0.45 \\
4 \cdot 2\end{array}$ & $\begin{array}{l}10.6 \\
3.7 \\
1.7 \\
0.9 \\
0.07 \\
1.14 \\
0.025 \\
1.67\end{array}$ & $\begin{array}{c}36 \cdot 4 \\
16 \cdot 2 \\
7 \cdot 1 \\
4 \cdot 3 \\
1 \cdot 62 \\
13.9 \\
0.41 \\
0.31\end{array}$ & $\begin{array}{l}3.8 \\
3.5 \\
1.6 \\
0.9 \\
0.07 \\
1.08 \\
0.035 \\
0.085\end{array}$ & $\begin{array}{l}<0.05 \\
<0.05 \\
<0.02 \\
<0.05 \\
<0.05 \\
<0.05 \\
<0.01 \\
<0.01\end{array}$ \\
\hline
\end{tabular}

Conversion: SI to traditional units-Viscosity: $1 \mathrm{mPa} . \mathrm{s}=1 \mathrm{cP} . \mathrm{SD}=$ standard deviation.

Table 2 Haematological and haemorheological changes associated with stopping cigarette smoking

\begin{tabular}{|c|c|c|c|c|c|c|c|}
\hline & \multicolumn{2}{|c|}{ Smoking } & \multicolumn{5}{|c|}{ Non-smoking } \\
\hline & Mean & $S D$ & $\begin{array}{l}2 \text { weeks } \\
\text { Mean }\end{array}$ & $S D$ & & $\begin{array}{l}2 \text { months } \\
\text { Mean }\end{array}$ & $S D$ \\
\hline $\begin{array}{l}\text { Whole blood viscosity (mPa.s) at: } \\
0 \cdot 1 / \mathrm{s} \\
1 / \mathrm{s} \\
10 / \mathrm{s} \\
100 / \mathrm{s} \\
\text { Red cell filtration }(\mathrm{No} \% / \mathrm{l} / \mathrm{min}) \\
\text { Plasma viscosity (mPa.s) } \\
\text { Haemoglobin b (g/dl) } \\
\text { Packed cell volume } \\
\text { Carboxyhaemoglobin (\%) }\end{array}$ & $\begin{array}{c}46.7 \\
19.8 \\
8.83 \\
5.06 \\
0.61 \\
1.68 \\
14.8 \\
0.46 \\
6\end{array}$ & $\begin{array}{l}(9) \\
(4 \cdot 36) \\
(1.45) \\
(1 \cdot 1) \\
(0.08) \\
(0.09) \\
(1.48) \\
(0.03) \\
(0.3)\end{array}$ & $\begin{array}{c}39.7 \\
19.4 \\
7.8 \\
4.65 \\
0.64 \\
1.72 \\
14.3 \\
0.46 \\
3.5\end{array}$ & $\begin{array}{l}(11.5) \\
(1.52) \\
(1.24) \\
(0.36) \\
(0.03) \\
(0.1) \\
(0.51) \\
(0.02) \\
(0.28)\end{array}$ & $\mathrm{p}<0.01$ & $\begin{array}{c}34.5 \\
16.4 \\
8.0 \\
4.4 \\
0.8 \\
1.66 \\
13.6 \\
0.42 \\
0.52\end{array}$ & $\begin{array}{l}(2.5) \\
(1.4) \\
(0.5) \\
(0.03) \\
(0.1) \\
(1){ }_{p<0.01} \quad 0.01\end{array}$ \\
\hline
\end{tabular}

Conversion: SI to traditional units-Viscosity: $1 \mathrm{mPa} . \mathrm{s}=1 \mathrm{cP} . \mathrm{SD}=$ standard deviation.

designed for red cell filtration and the results standardised to a white cell count of $7.5 \times 10^{9} / 1^{8}$

5 Plasma fibrinogen, measured by the Ogston and Ogston modification of the Menzies and Ratnoff technique. ${ }^{9}$

6 Carboxyhaemoglobin concentration (\%) measured spectrophotometrically.

Analysis was performed using the paired $t$-test for small numbers.

\section{Results}

\section{SMOKERS $v$ NON-SMOKERS}

Highly significant differences were observed in whole blood viscosity at all the shear rates measured, plasma viscosity, plasma fibrinogen concentrations, packed cell volume, and carboxyhaemoglobin concentrations (Table 1 and Figs. 1 and 2).

\section{CHANGES ASSOCIATED WITH STOPPING CIGARETTE SMOKING}

Table 2 and Figs 3 and 4 show the differences obtained after cigarette smoking was stopped for two weeks and that only those relating to carboxyhaemoglobin concentrations and whole blood viscosity at a shear rate of $0 \cdot 1 / \mathrm{s}$ in men (Table 3) achieved significance. Trends for improvement can, however, be seen in all other variables. Moreover, it is clear from Table 2 that at two months the data from the two subjects studied were similar to those from non-smokers (Table 1).

\section{CORRELATION BETWEEN}

CARBOXYHAEMOGLOBIN CONCENTRATION AND HAEMATOLOGICAL AND HAEMORHEOLOGICAL

VARIABLES

In both parts of our study we found no correlation between carboxyhaemoglobin concentrations and any of the variables measured.

\section{Discussion}

Our comparative findings in smokers and nonsmokers are generally in agreement with those previously reported. Dintenfass, studying 125 police-

Table 3 Mean changes in whole blood viscosity (mPa.s) associated with stopping smoking according to sex

\begin{tabular}{cll}
\hline Shear rate $(l s)$ & Smokers & Non-smokers \\
\hline & \multicolumn{1}{c}{ Men $(n=7)$} & \\
0.1 & 55.6 & $33.68 \mathrm{p}<0.01$ \\
1 & 21.1 & 18.2 \\
10 & 8.98 & 8.18 \\
100 & 5.28 & 4.8 \\
& Women $(n=5)$ & \\
0.1 & 44.7 & 38.0 \\
1 & 19.98 & 17.03 \\
10 & 8.1 & 7.1 \\
100 & 5.2 & 4.23 \\
\hline
\end{tabular}




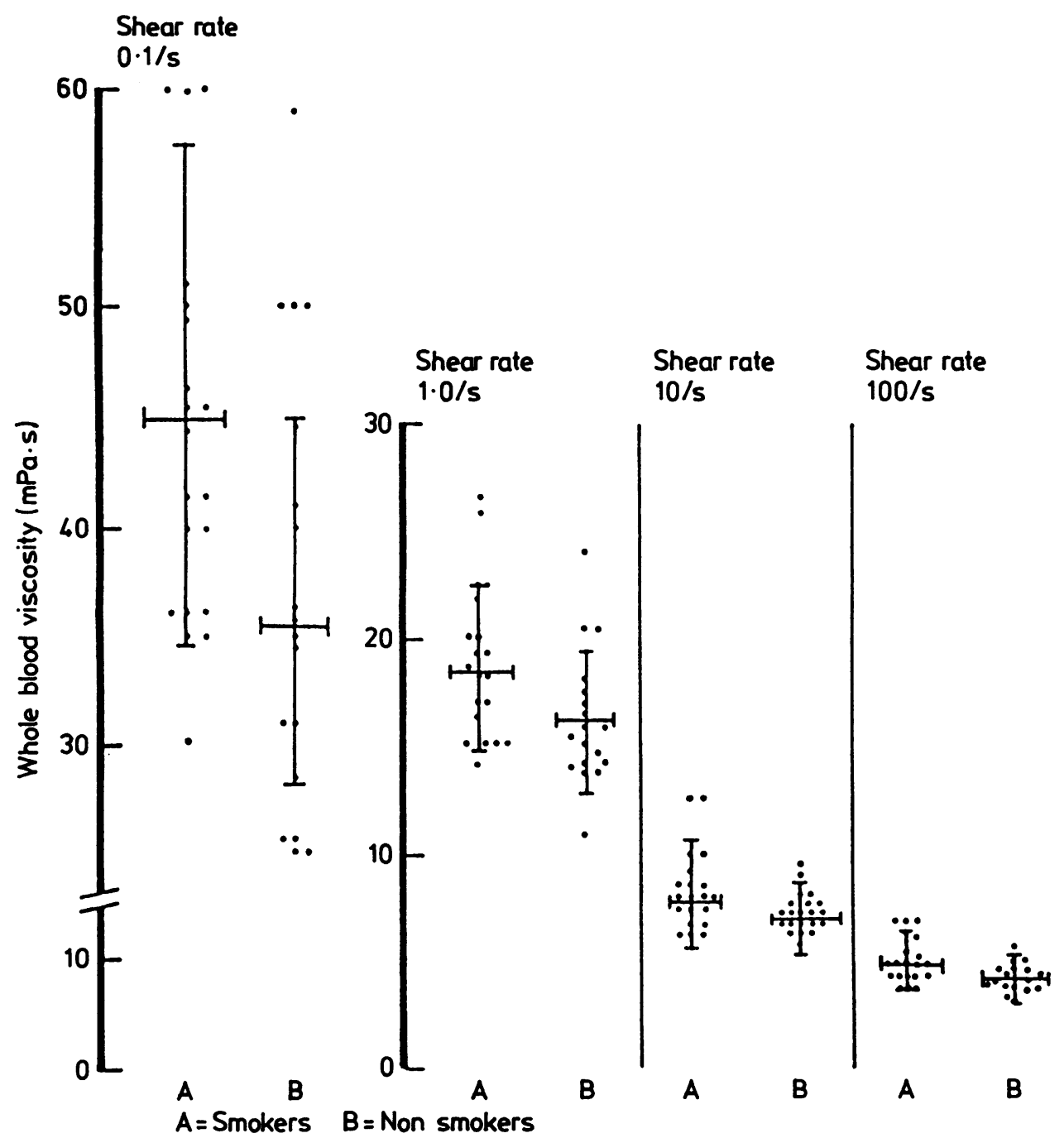

Fig. 1 Shear rates of whole blood viscosity (mPa.s) in smokers and non-smokers.

men, found that smokers had an increase in packed cell volume, plasma fibrinogen concentration, and both plasma and whole blood viscosities, ${ }^{4}$ while other studies reported a raised whole blood viscosity, particularly at low shear rates. ${ }^{1011}$

In contrast, data on the deformability of red cells in smokers are conflicting, but this may merely reflect differences in methodology or populations studied. Thus Grigoleit et al reported a reduced red cell filtration in men but not in women ${ }^{12}$ while Ehryl and Landgraf recorded a slight but not significant reduction in red cell filtration in both sexes. ${ }^{13}$ Additionally after "acute" smoking of two or three cigarettes Lagrue et al and Lowe and coworkers showed a significant reduction in red cell filtration, ${ }^{14} 15$ whereas Ehrly and Schumpf ${ }^{16}$ found no significant alteration after only one cigarette was smoked. The reasons for the reduction in deformability have not yet been established, but Norton and Rand suggested that erythrocyte geometrical and membrane properties are the relevant factors rather than alterations affecting cell size or internal viscosity. ${ }^{17}$ In addition, these authors confirmed that the acute effects of carbon monoxide on the physicochemical state of haemoglobin did not seem to be important.

The follow up part of our study was unfortunately limited by two salient factors. Firstly, although we 


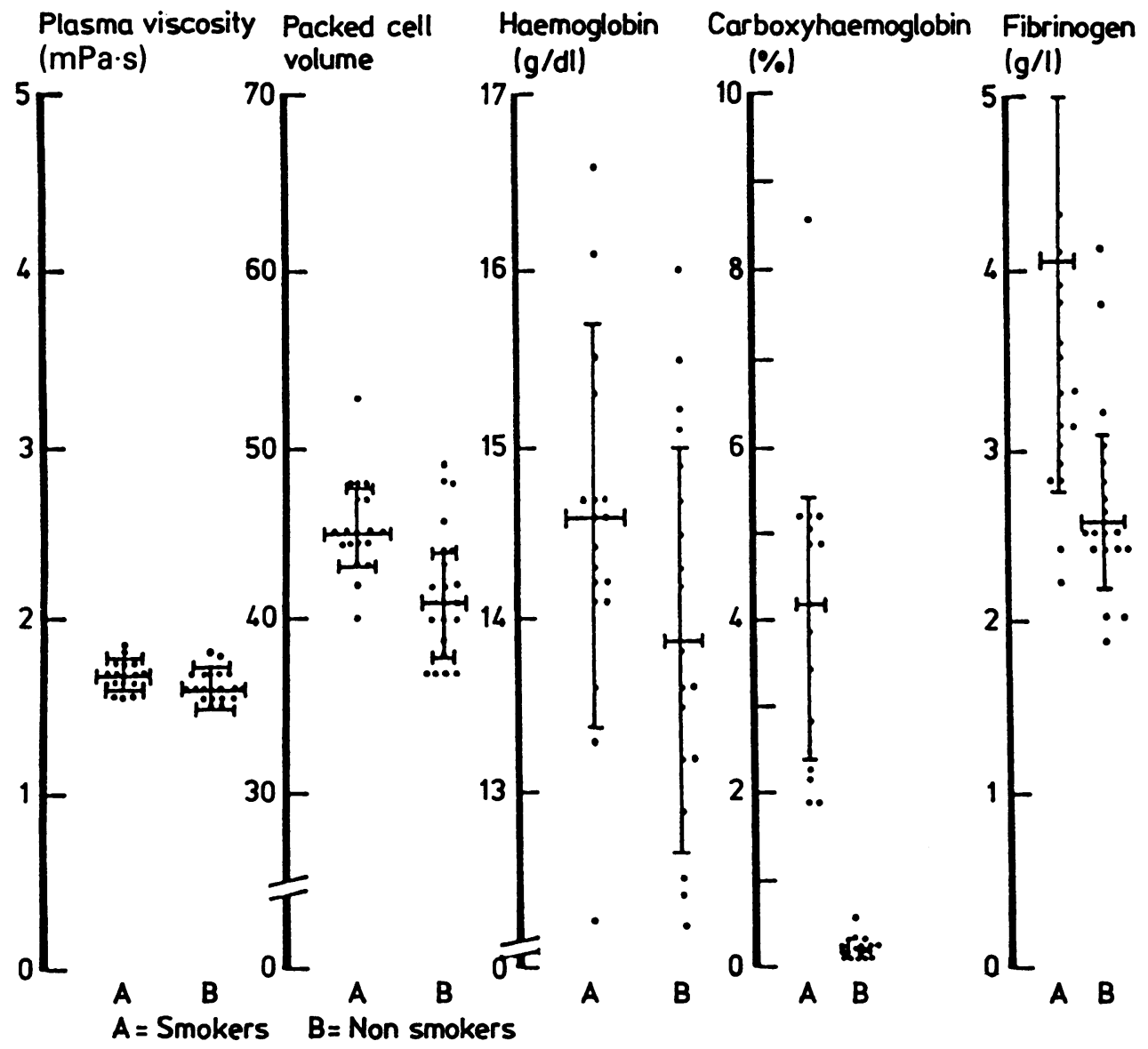

Fig. 2 Plasma viscosity (mPa.s) packed cell volume, haemoglobin and carboxyhaemoglobin concentrations, and fibrinogen in smokers and non-smokers.

initially studied 20 smokers, only 10 managed to break completely or limit severely their smoking habit and, secondly, when restudied our volunteers had stopped smoking for only two weeks, except for two, although we made a strong effort to motivate all of them to give up smoking for longer. Even with these restrictions we observed improvements in all the haemorheological variables measured, although this attained significance only in whole blood viscosity in men at low shear rates. For obvious reasons few prospective studies have been undertaken let alone completed on subjects stopping smoking. Markman, however, reported a prompt fall in packed cell volume in smokers who were not allowed to smoke after their admission to hospital for various reaons. ${ }^{18} \mathrm{He}$ attributed this fall to exposure to carbon monoxide (carbon monoxide reduces plasma volume) and changes of circulating catecholamines induced by smoking.

Of particular interest was our inability to find any correlation between carboxyhaemoglobin concentrations and the wide range of haematological and haemorheological variables measured. Numerous authors have shown that there is a poor correlation between the number of cigarettes smoked and random carboxyhaemoglobin concentrations. ${ }^{19-23}$ In smokers carboxyhaemoglobin concentrations show wide fluctuations throughout the day and are influenced by recent smoking, type and strength of tobacco, mode of smoking, time of day, exercise, and smoking patterns. It is now recognised that the carboxyhaemoglobin concentration in an individual smoker cannot be predicted by the number of cigarettes smoked and that there is a large variation in carboxyhaemoglobin concentration between people who smoke the same daily amount of tobacco. ${ }^{23}$ 


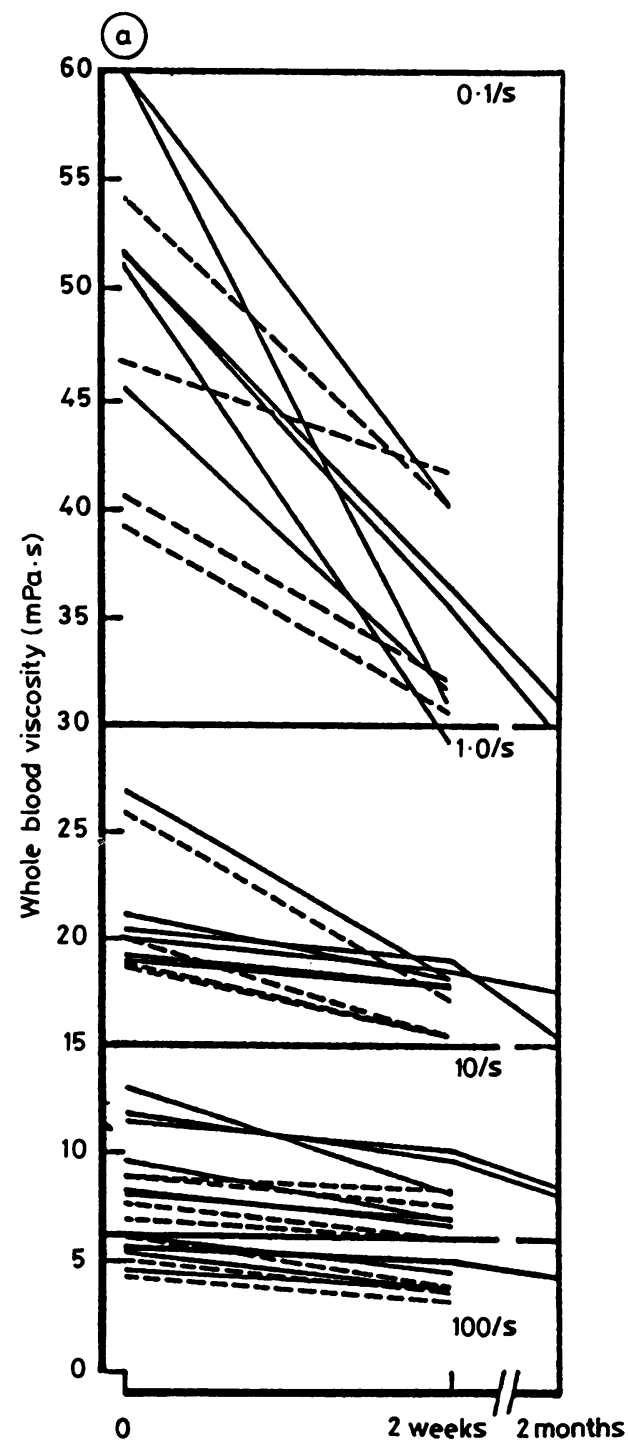

In view of these findings the relevance of a single measurement of carboxyhaemoglobin is open to question.

In a recent study Ho Yen et al reported that smokers, averaging 25 cigarettes a day, produced no change in their carboxyhaemoglobin concentration after their cigarette consumption had been halved. ${ }^{24}$ Our findings do not agree with these results, but in our follow up study the volunteers had completely or nearly completely stopped smoking, whereas all the subjects in that study were still smoking 10-15 cigarettes a day. Though it is therefore not surpris-

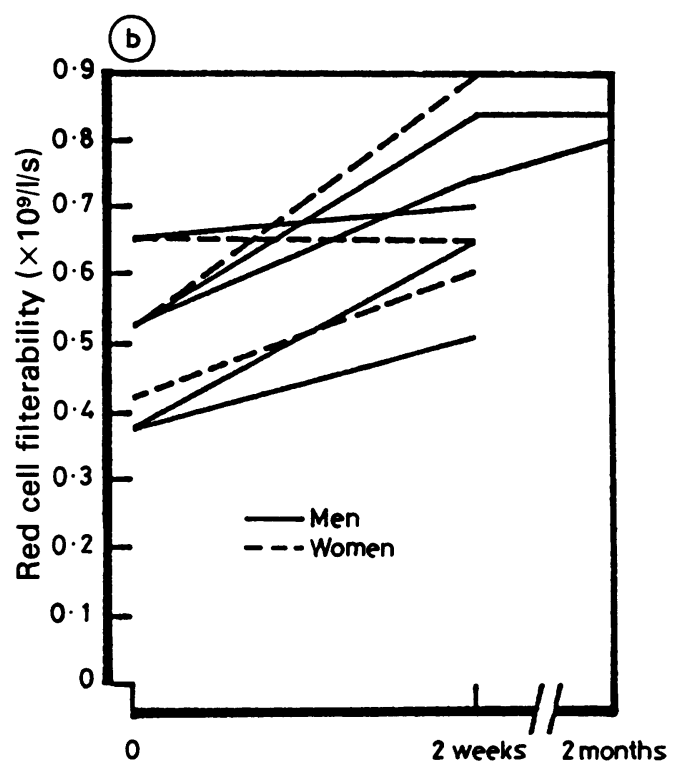

Fig. 3a Whole blood viscosity (mPa.s) at $0 \cdot 1,1 \cdot 0$, 10 , and 100/s (shear rates) before and at two weeks and two months after smoking had been stopped.

Fig. 3b Red cell filterability index before and at two weeks and two months after smoking had been stopped.

ing that carboxyhaemoglobin concentrations dropped significantly in our subjects, we would at the same time contend that these concentrations are more dependent on the way cigarettes are smoked than on their number.

Several studies have shown that the metabolic and haemorheological responses to cigarette smoking vary with sex. Thus Hill et al showed higher plasma thiocyanate concentrations in women than in men when both sexes smoked more than 20 a day, and they also showed that older men seem to metabolise nicotine to cotinine less efficiently than women. ${ }^{22}$ 


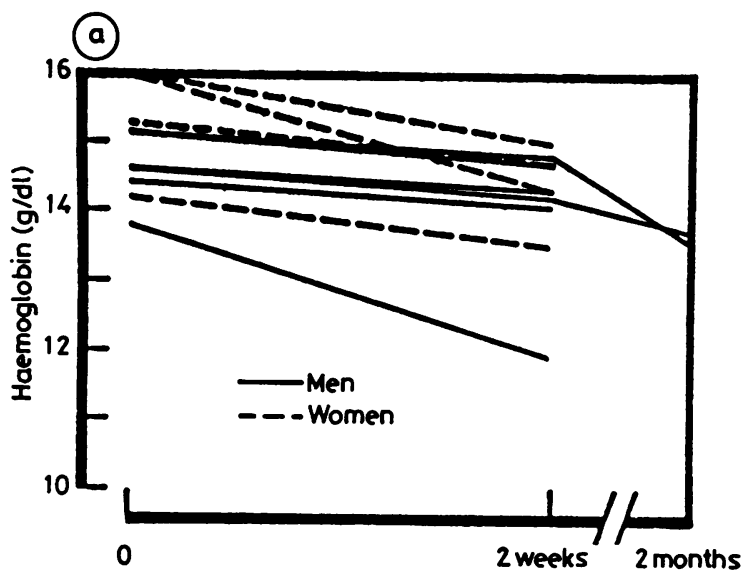

Fig. 4a Haemoglobin concentration ( $g / d l)$ before and at two weeks and two months after smoking had been stopped.

Fig. 4b Carboxyhaemoglobin concentrations before and at two weeks and two months after smoking had been stopped.

Furthermore, it was only in male smokers that Grigoleit and coworkers found red cell filtration to be decreased ${ }^{12}$ and Ehrly et al found whole blood viscosity to be increased. ${ }^{16}$ These differences between the sexes have not been adequately explained although different smoking habits may be the cause of the discrepancies. In this context it is interesting to note, however, that the whole blood viscosity improved significantly only in men after cigarette smoking had been stopped.

In this study we showed that cigarette smoking has several deleterious effects on the properties of blood flow and that these are quickly reversible or partly so once smoking has stopped. Though patient compliance is difficult to obtain, further prospective studies should be attempted to confirm the early improvements we noted and to assess whether they would be maintained for longer periods. Finally, we emphasise that the measurement of carboxyhaemoglobin should not be used as an index of inhalation of smoke.

\section{References}

' Fowler GH. Changing behaviour-smoking. The Medical Annual 1983:151-66.

2 Jenkins PJ, Harper RW, Nestel PJ. Severity of coronary atherosclerosis related to lipoprotein concentration. $\mathrm{Br}$ Med J 1978;it:388-91.

${ }^{3}$ Anonymous. Haemostatic factors and coronary heart disease [Editorial]. Lancet 1981;i:22-3.

4 Dintenfass L. Elevation of blood viscosity, aggregation of red

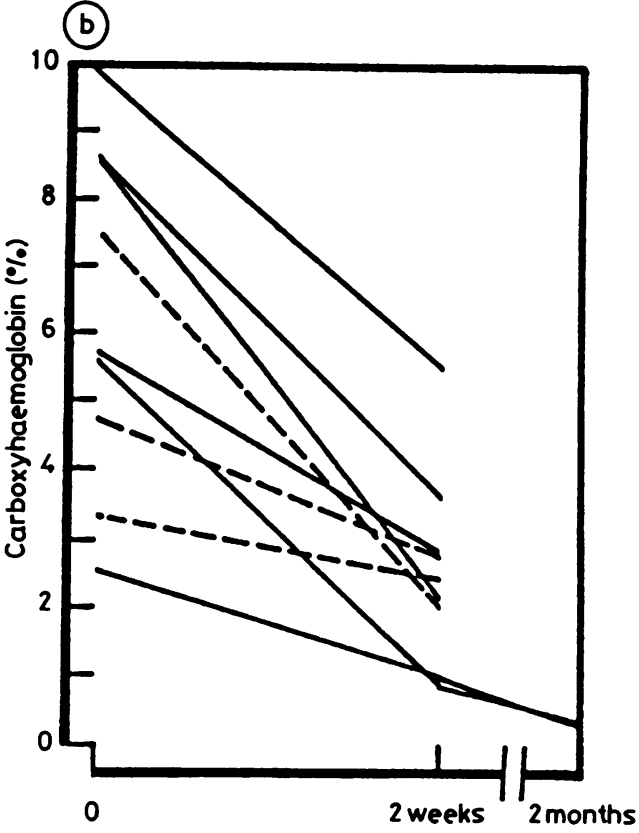

cells, haematocrit values and fibrinogen levels in cigarette smoking. Med J Aust 1975;1:617-20.

${ }^{5}$ Isager $\mathrm{H}$, Hagerup L. Relationship between cigarette smoking and high packed cell volume and haemoglobin levels. Scand J Haematol 1971;8:241-4.

- Sutton SR, Russell MAH, Iyer R, Feyerabend C, Saloojee Y. Relationship between cigarette yields, puffing patterns and smoke intake; evidence for tar compensation. $\mathrm{Br} \mathrm{Med} J$ 1982;285:600-3.

7 Reid HL, Barnes AJ, Lock PJ, Dormandy JA, Dormandy TL. A simple method of measuring erythrocyte deformability. $J$ Clin Pathol 1976; 29:855-8.

${ }^{8}$ Alderman MJ, Ridge A, Morley AA, Ryall RG, Walsh JA. Effect of total leucocyte count on whole blood filterability in patients with peripheral vascular disease. J Clin Pathol 1981;34:163-6.

- Ogston D, Ogston CM. Plasma fibrinogen and plasminogen levels in health and ischaemic heart disease. J Clin Pathol 1966; 19:352-5.

${ }^{10}$ Chmiel H, Effert S, Mathey D. Rheologische Veränderung des Blutes beim akuten Herzinfarkt und dessem Risikofaktoren Disch Med Wochenschr 1973;98:1641-6.

"Lowe GDO, Drummond MM, Forbes CS, Barbanel JC. The effects of age and cigarette smoking on blood and plasma viscosity in men. Scott Med J 1980;25:13-17.

${ }_{12}$ Grigoleit HG, Leonhardt H, Jacobi G. Mikrorheologische Untersuchungen an Gesunden. Dtsch Med Wochenschr 1978; 103:329-34.

${ }^{13}$ Landgraf H, Ehrly AM. "Chronic" cigarette smoking and flow properties of blood. Clin Haemorheol 1981;3:241-9.

14 Lagrue G, Faucher G, Gallais M, Grillot A, Brannellec A. Red cell filterability and candiovascular risk factors. Thromb Haemostas 1979; 42:106.

is Lowe GDO, Drummond MM, Forbes CD, Barbanel JC, Smith S. Effects of cigarette smoking in blood rheology. Scott Med J 1980;25:13-17.

16 Ehrly AM, Schrimpf WJ. Der EinfluB des "akuten" Zigarettenraucens auf die Verfornbarkeit von Erythrozyten. Herz/ 
Kreislauf 1978;10:245-6.

${ }^{17}$ Norton JM, Rand PW. Decreased deformability of erythrocytes from smokers. Blood 1981;57:671-4.

${ }^{18}$ Markman P. Falling PCV on cessation of smoking. JAMA 1981;245:1314-45.

${ }^{19}$ Zahran F, Youssif AA, Habib M, Baig A. A study of COHb of cigarette and sheesa smokers in Saudi Arabia. Am J Public Health 1982;72:722-4.

${ }^{20}$ Chait LD, Griffiths RR. Smoking behaviour and tobacco smoke intake: response of smokers to shortened cigarettes. Clin Pharmacol Therap 1982;32:90-7.

21 Jamson L, Lindell SE, Trell E, Larme P. Smoking habits and COHb.J Epidemiol Community Health 1981;35:271-3.
${ }^{22}$ Hill P, Haley NJ, Wynder EL. Cigarette smoking: COHb, plasma nicotine, cotinine and thiocyanate vs self reported smoking data and cardiovascular disease. J Chron Dis 1983;36:439-49.

${ }^{23}$ Wald M, Howard S, Smith PG, Bailey A. Inhaling habits among smokers of different types of cigarettes. Thorax 1980; 35:925-8.

${ }^{24}$ Ho Yen DO, Spence VA, Moody JP, Walker WF. Why smoke fewer cigarettes? Br Med J 1982;284:1905-7.

Requests for reprints to: Dr G Galea, Aberdeen and NE Scotland Blood Transfusion Service, Aberdeen Royal Infirmary, Foresterhill, Aberdeen, Scotland AB9 2ZD. 